\title{
Author Correction: The energy cost of polypeptide knot formation and its folding consequences
}

\author{
Andrés Bustamante1, Juan Sotelo-Campos², Daniel G. Guerra ${ }^{3}$, Martin Floor ${ }^{1}$, Christian A.M. Wilson', \\ Carlos Bustamante ${ }^{3,4} \&$ Mauricio Báez ${ }^{1}$
}

Correction to: Nature Communications https://doi.org/10.1038/s41467-017-01691-1, pubilshed online 17 November 2017

The original version of this article contained an error in the spelling of the author Christian A.M. Wilson, which was incorrectly given as Christian M.A. Wilson. This has now been corrected in both the PDF and HTML versions of the article.

Published online: 14 December 2017

\begin{abstract}
cc) reproduction in any medium or format, as long as you give appropriate credit to the original author(s) and the source, provide a link to the Creative Commons license, and indicate if changes were made. The images or other third party material in this article are included in the article's Creative Commons license, unless indicated otherwise in a credit line to the material. If material is not included in the article's Creative Commons license and your intended use is not permitted by statutory regulation or exceeds the permitted use, you will need to obtain permission directly from the copyright holder. To view a copy of this license, visit http://creativecommons.org/licenses/by/4.0/.
\end{abstract}

(C) The Author(s) 2017

\footnotetext{
${ }^{1}$ Departamento de Bioquímica y Biología Molecular, Facultad de Ciencias Químicas y Farmacéuticas, Universidad de Chile, Santos Dumont 964, Independencia, Santiago, 8380494, Chile. ${ }^{2}$ Departamento Académico de Ciencias Exactas, Facultad de Ciencias y Filosofía, Universidad Peruana Cayetano Heredia, Av. Honorio Delgado 430, San Martin de Porras, Lima-31 15102, Peru. ${ }^{3}$ Laboratorio de Moléculas Individuales, Facultad de Ciencias y Filosofía, Universidad Peruana Cayetano Heredia, Av. Honorio Delgado 430, San Martin de Porras, Lima-31 15102, Peru. ${ }^{4}$ Department of Molecular and Cell Biology, Department of Physics and Department of Chemistry, Kavli Energy Nanoscience Institute, and Howard Hughes Medical Institute, University of California, Berkeley, CA 94720, USA. Andrés Bustamante and Juan Sotelo-Campos contributed equally to this work. The original article can be found online at https:// doi.org/10.1038/s41467-017-01691-1. Correspondence and requests for materials should be addressed to C.B. (email: carlosjbustamante2@gmail.com) or to M.Báe. (email: mauricio.baez@ciq.uchile.cl)
} 